\title{
EITC Continues to Reach Families in Poor Places
}

\author{
Andrew Schaefer, Marybeth J. Mattingly, Kennedy Nickerson, and Jessica A. Carson
}

$\mathrm{R}$ ecent proposals in the House and Senate (for example, the Grow American Incomes Now Act) focus on amplifying the Earned Income Tax Credit (EITC) - a refundable tax credit for low-income workers- to compensate for growing wage inequity. We find that the share of EITC filers who are families with children is especially high in the poorest counties (those counties outlined in black on Map 1), including many places throughout the South. Many of these counties are nonmetropolitan counties (see Map 2), suggesting that the EITC can provide safety net support in places where other social services may be less available. While an EITC expansion could be costly, existing research shows that its effects on poverty reduction, employment, and both children's health and achievement are considerable, and therefore, worth considering in the scheme of ongoing broad tax revisions.

\section{MAP 1: SHARE OF EITC FILERS WHO ARE FAMILIES WITH ANY CHILDREN AND HIGH CHILD POVERTY}

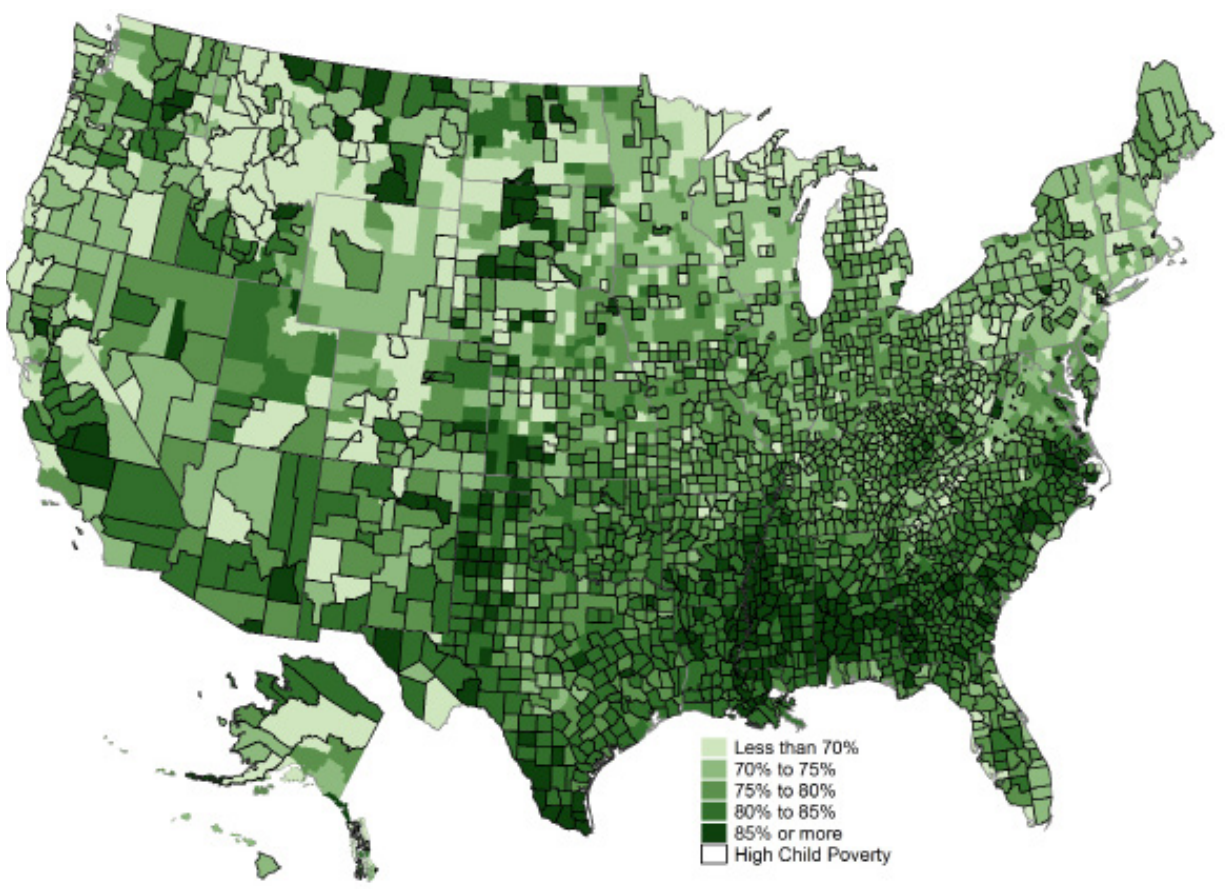

Note: "High child poverty" is defined as places in which more than 20 percent of children live below the federal poverty threshold. Source: Brookings/RS 2013; ACS 2008-2012

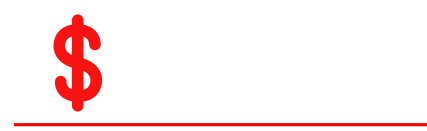

The Earned Income Tax Credit provides tax relief to working people with low to moderate income, with much larger credits for tax filers with children. The credit is refundable, meaning that the EITC reduces the amount of tax owed, and any amount above that may be issued as a refund.

See related publications at carsey.unh.edu

- State EITC Programs Provide Important Relief to Families in Need (February 2017)

- Federal EITC Kept 2 Percent of the Population Out of Poverty (November 2015)

- Proposed EITC Expansion Would Increase Eligibility and Dollars for Rural and Urban "Childless" Workers (June 2014)

This analysis was made possible by funding from the Annie E. Casey Foundation and anonymous donors. 